\title{
KONSEP AL-IJARAH MUNTAHIYAH BITTAMLIK DALAM SYARIAH \\ ISLAMIYAH
}

\author{
Lian Fuad, Muhammad Faiz \\ Institut Pesantren KH. Abdul Chalim Pacet Mojokerto \\ Email: cakyan85@gmail.com
}

\begin{abstract}
ABSTRAK
Islamic religion encompasses all aspects of the life of its followers. In economic matters, Islam opens enormous opportunities in terms of innovation as long as it does not conflict with the basics of Islamic economics. Akad Al-Ijarah Muntahiyah Bittamlik is a form of innovation that does not exist in the discussion of classical scholars, in which there are two models of contract that are interrelated and mutually reinforcing. This contract is now widely used by Islamic banking for financing. This contract also explains that in Islam there is also a solution to economic problems to raise the standard of living of the people in accordance with the guidelines of Islamic Shari'a.
\end{abstract}

Kata Kunci: Akad Al-Ijarah Muntahiya Bittamlik, Perbankan Syariah, dua akad dalam satu akad, Hukum Islam.

\section{PENDAHULUAN}

Perkembangan perbankan syariah menuntut untuk lebih kompetitif dalam menawarkan produk yang bisa bersaing dengan bank-bank konvensional. Ulama-ulama islam kontemporer dituntut untuk menggali dasar hukum yang bisa dijadikan rujukan terhadap akad model baru sesuai dengan perkembangan zaman selain juga mempertahankan model akad yang sudah ada sejak zaman nabi Muhammad. Model akad baru adalah suatu keharusan dalam zaman yang berkembang dengan cepat. 
Akad yang ditawarkan oleh akademisi islam untuk mengembangkan produk bank syariah salah satunya adalah akad pembiayaan dengan nama Al-Ijarah Al Muntahiyah bit Tamlik atau financial leasing with purchase. Akad ini tergolong baru karena menggabungkan antara dua akad yaitu akad sewa menyewa (الإجارة) dengan akad hibah atau jual beli di akhir masa sewa untuk berpindahnya kepemilikan suatu harta. ${ }^{1}$ Akad model ini dapat digambarkan seperti akad penggabungan dua model akad (hybrid contract) antara akad sewa menyewa dengan akad hibah atau sewa menyewa dengan akad jual beli. Penggabungan ini bentuk kesepakatan dua belah pihak untuk melakukan suatu kontrak muamalah yang meliputi dua akad atau lebih. Kesepakatan ini berimplikasi pada hak dan kewajiban antara pihak yang melakukan kesepakatan yang tidak tidak bisa dipisahkan, karena akan berdampak secara hukum. Ukuran produk perbankan yang bisa dikategorikan memenuhi standar Prinsip-prinsip Syariah atau tidak ialah dengan melihat ketentuan-ketentuan yang berlaku pada akad tersebut.

Bentuk akad baru seperti ini merupakan terobosan yang bagus, tapi akad ini masih meninggalkan beberapa permasalahan dalam perbedaan ulama tentang penggabungan dua akad menjadi satu yang sampai saat ini masih menjadi permasalahan khilafiyah. Berlandaskan masalah tersebut, perlu dilakukan sebuah kajian yang komprehensif tentang Al-Ijarah Muntahiyah Bittamlik dalam perspektif Syariah Islamiyah.

\section{DEFINISI}

Al-Ijarah Muntahiyah Bittamlik atau financial leasing with purchase option atau akad sewa menyewa yang diakhiri dengan kepemilikan baik dengan hibah atau jual beli merupakan istilah yang baru dan tidak ada dalam kitab-kitab turats disemua madzhab fikih. Untuk mengetahui definisi term baru ini, penulis akan mengulas secara parsial dari term diatas untuk mendapatkan gambaran yang jelas tentang akad-akad yang ada dalam term yang baru ini.

Term Al-Ijarah Muntahiyah Bittamlik terdiri dari dua akad musamma yaitu Al-Ijarah (sewa menyewa) dan At-Tamlik (kepemilikan). Al-Ijarah menurut etimologi berasal dari

\footnotetext{
${ }^{1}$ Adiwarman A. Karim, Bank Islam Analisis Fiqih dan Keuangan, Cetakan ke-3, (Jakarta: Raja Grafndo Persada, 2006), h. 165.
} 
kata الأجر yang berarti imbalan atas pekerjaan ${ }^{1}$ atau pahala. Sedangkan al-Ijarah berarti pekerjaan yang menyebabkan seseorang mendapatkan pahala atau imbalan. Ulama fikih mendefinisikan secara terminologi term ini yaitu suatu akad yang mendatangkan manfaat yang jelas lagi mubah berupa suatu dzat yang ditentukan ataupun yang disifati dalam sebuah tanggungan, atau akad terhadap pekerjaan yang jelas dengan imbalan yang jelas serta tempo waktu yang jelas pula. ${ }^{2}$ Dewan Syariah Nasional dalam fatwanya mendefinisikan Al-Ijarah "Akad pemindahan hak guna (mamfaat) atas suatu barang atau jasa dalam waktu tertentu melalui pembayaran sewa atau upah, tanpa diikuti dengan pemindahan kepemilikan barang itu sendiri ${ }^{3}$. Dengan demikian, dalam akad ijarah tidak ada perubahan kepemilikan, tetapi hanya pemindahan hak guna saja dari yang menyewakan kepada penyewa. Akad Ijarah merupakan akad yang menggunakan jasa, baik itu jasa yang berupa barang atau jasa yang berupa tenaga. Untuk sesuatu manfaat yang berupa barang dinamakan sewa-menyewa dan untuk manfaat yang berupa tenaga dinamakan upah. Akad ijarah berbeda dengan akad ji'alah yang mana sistem pengupahannya tergantung target yang dicapai. Pada akad ini tidak terjadi perpindahan kepemilikan penuh terhadap objek akad melainkan terjadi perpindahan kepemilikan manfaat dari objek akad.

Term At-Tamlik secara etimologi berarti menjadikan orang lain memiliki sesuatu, yang menyebabkan seseorang bisa mentasarufkan secara sempurna. Adapun definisi A-Tamlik secara terminologi tidak berbeda dengan makna etimologi. Term at-tamlik memberikan pengertian bahwa kepemilikan harus secara penuh, tidak parsial. Kepemilikan parsial bisa berupa kepemilikan benda saja seperti barang yang disewakan, yang mana barang tersebut tetap menjadi milik pemiliknya meskipun orang yang memiliki tidak bisa memanfaatkannya atau kepemilika atau manfaat saja seperti barang sewaan yang ada ditangan penyewa yang mana orang tersebut mempunyai kuasa manfaat secara penuh, tetapi orang yang menyewa tidak memiliki barang tersebut.

\footnotetext{
${ }^{1}$ Ibid., h. 128

${ }^{2}$ Muhammad Syaf'i Antonio, Bank Syariah: dari Teori ke Praktik, (Jakarta: Gema Insani, 2001), h. 117

3 Muhammad. Manajemen Pembiayaan Bank Syari'ah. (Yogyakarta: UPP Akademi Manajemen Perusahaan YKPN 2005), hal, 147
} 
Term gabungan antara ijarah dan tamlik menjadi Al-Ijarah Al-Muntahiyah Bittamlik menurut Habsi Ramli adalah "Akad sewa menyewa antara pemilik objek sewa dan penyewa untuk mendapatkan imbalan atas objek sewa yang disewakannya dengan opsi perpindahan hak milik objek sewa pada saat tertentu sesui dengan akad sewa". ${ }^{1}$

Majma' Fiqh Islami dalam mu'tamar kelima membahas tentang Al-Ijarah Al-Muntahiyah Bittamlik berlaku pada 2 model muamalah:

1. Jual beli sistem kredit dengan jaminan yang memadai

2. Akad sewa dengan memberikan pilihan pada pemilik barang kepada orang yang menyewa setelah menyelesaikan semua jenis kewajiban kreditnya selama masa menyewa salah satu dari:

a. menambah waktu sewa

b. menghentikan akad sewa dan mengembalikan barang kepada pemiliknya

c. menjual barang yang disewakan dengan harga pasaran ketika berakhirnya masa sewa. $^{2}$

Dr Asy-Syamil mendeskripsikan Al-Ijarah Al-Muntahiyah Bittamlik yaitu suatu akad yang dilakukan oleh Bank Islam untuk menyewakan barang kepada seseorang dalam waktu tertentu, terkadang harga kredit lebih tinggi dari harga normal, yang mana orang yang menyewa bisa memiliki barang yang disewa setelah habis waktu sewanya. Jika orang yang menyewa melunasi uang sewa, barang sewaan menjadi milik penyewa dengan akad hibah (pemberian) atau uang cicilan terakhir diibaratkan menjadi uang jual beli terhadap barang yang disewa. ${ }^{3}$

Sedangkan undang-undang Indonesia dalam yang memberikan definisi tentang Al-Ijarah Al-Muntahiyah Bittamlik dengan mengeluarkan Undang-Undang Republik Indonesia Nomor 21 Tahun 2008 tentang Perbankan Syariah. Dalam UU ini, tidak disebutkan secara jelas mengenai Al-Ijarah Al-Muntahiyah Bittamlik, tetapi klausa Al-Ijarah AlMuntahiyah Bittamlik berada pada bahasan penyaluran pembiayaan penyewaan. Dalam pasal 19 ayat 1 dan 2 poin $\mathrm{f}$ berbunyi: "Menyalurkan pembiayaan penyewaan barang

\footnotetext{
${ }^{1}$ Hasbi Ramli. Teori Dasar Akutansi Syariah. (Jakarta: Renaisan, 2005), h. 63

${ }^{2}$ Wahbah Zuhaili, Al-Fiqhu Al-Islami Wa Adillatuhu, (Damaskus: Darul Fikri), h. 5161

${ }^{3}$ Mahmud Abdul Karim Ahmad Irsyid, Asy-Syamil Fi Muamalat Wa Amaliyatil Masharif Al-Islamiyah, (Jordania: Darun Nafais, 2007), h 63.
} 
bergerak atau tidak bergerak kepada Nasabah berdasarkan Akad Ijarah dan/atau sewa belidalam bentuk Ijarah Muntahiya Bittamlik atau akad lain yang tidak bertentangan dengan Prinsip Syariah". ${ }^{1}$

Dalam Surat Edaran Bank Indonesia No. 5/26/ BPS/2003 tentang Pedoman Akuntansi Perbankan Syariah Indonesia halaman 111, yang dimaksud dengan Ijarah Muntahiya Bittamlik adalah perjanjian sewa-menyewa suatu barang antara lessor/muajjir (pemberi sewa) dengan lessee/musta'jir (penyewa) yang diakhiri dengan perpindahan hak milik objek sewa.

Berdasarkan Buku Kodifkasi Produk Perbankan Syariah, Lampiran SEBI No. 10/31/ DPBS tanggal 7 Oktober 2008 Perihal Produk Bank Syariah dan Unit Usaha Syariah PBI No. 10/17/PBI/2008 tanggal 25 September 2008, yang dimaksud dengan Ijarah Muntahiya Bittamlik adalah transaksi sewa-menyewa antara pemilik objek sewa dan penyewa untuk mendapatkan imbalan atas objek sewa yang disewakan dengan opsi perpindahan hak milik objek sewa.

Berdasarkan fatwa Dewaan Syariah Nasional No. 27/DSNMUI/ III/2002 tentang AlIjarah Al-Muntahiyah Bittamlik, yang dimaksud dengan sewa beli (al-ijarah almuntahiyah bittamlik), yaitu perjanjian sewa menyewa yang disertai opsi pemindahan hak milik atas benda yang disewa, kepada penyewa, setelah selesai masa sewa. ${ }^{2}$

\section{Rukun Akad Al-Ijarah Al-Muntahiyah Bittamlik}

Dalam Kompilasi Hukum Ekonomi Syariah (KHES), rukun diatur dalam pasal 278 KHES yang menyebutkan "Rukun dan syarat dalam ijarah dapat diterapkan dalam pelaksanaan Ijarah Muntahiyah bi Tamlik". Berdasar pada pasal tersebut dapat dipahami bahwa rukun akad ini sama seperti akad ijarah yaitu:

1. Penyewa (musta'jir) yang dinamakan lesse, dalam perbankan penyewa dinamakan disebut nasabah

\footnotetext{
${ }^{1}$ Undang-Undang Republik Indonesia tentang Perbankan Syariah Nomor 21 Tahun 2008, (Yogyakarta: Pustaka Mahardika, 2011), h. 14-16.

2 Fatwa Dewaan Syariah Nasional No. 27/DSNMUI/ III/2002 tentang Al-Ijarah Al-Muntahiyya Bi AlTamlik.
} 
2. Pemilik barang (muajjir) yang dinamakan lessor, dalam perbankan pemilik barang adalah bank

3. Barang/objek akad (ma'jur) adalah barang yang disewakan

4. Shigot (ijab dan qabul) ${ }^{1}$

\section{Akad Al-Ijarah Al-Muntahiyah Bittamlik menurut Syariat Islam}

Akad Al-Ijarah Al-Muntahiyah Bittamlik adalah akad bentuk baru yang tidak ditemukan dalam bentuk akad musammaa, akan tetapi karakteristiknya mempunyai kesamaan dengan akad musamma khususnya akad ijarah. Akad ini sudah memenuhi asas dalam perjanjian syariah seperti asas kebolehan, kebebasan manusia untuk melakukan inovasi dalam perkara muamalah, sesuai dengan kaidah fikih

$$
\text { الأصل في الأشياء الإباحة حتى يدل الدليل على التحريم. }
$$

"Pada dasarnya, segala sesuatu boleh dilakukan kecuali ada dalil yang mengharamkannya".2

Meskipun akad ini tergolong baru, tapi akad ini tidak menyalahi peraturan dalam syariat islam, karena kaidah fiqhiyyah mengakomodir semua yang sifatnya muamalah itu dikembangkan menurut zaman yang berlaku.

Akad ini juga mengikuti asa kejujuran dan kebenaran, asas ini berkaitan erat dengan proteksi syariat terhadap praktek-praktek yang mengandung gharar, maisir ataupun riba. Praktek gharar bisa terjadi jika tidak ada unsur ketidak jelasan dalam ma'qud alaih atau objek akad, bisa berupa tidak bisa diserahkan ketika akad, tidak diketahui kadar barang. Sementara akad Al-Ijarah Al-Muntahiyah Bittamlik jelas dalam ma'qud alaihnya, baik dari sisi rukun dan syarat yang berlaku. Akad ini juga jauh dari praktek maisir atau gambling, karena akad ini memberikan batasan yang jelas mengenai hak dan kewajiban yang harus dilakukan oleh masing-masing pihak ketika melakukan akad.

\footnotetext{
${ }^{1}$ Kompilasi Hukum Ekonomi Syariah (KHES), Pasal 251 tentang Rukun Ijarah.

${ }^{2}$ Muhammad Mushtafa az-Zuhaili, al-Qawaid al-Fiqhiyyah wa Tathbiqatuha fi al-Madzahib al-Arba'ah, juz 1, h. 190.
} 


\section{Tinjauan syariah tentang penggabungan dua akad menjadi satu}

Rasululllah dengan tegas melarang penggabungan dua akad menjadi satu, karena di indikasikan akan terjadi gharar dan juga maisir. Pelarangan ini diriwayatkan oleh Imam Ahmad,

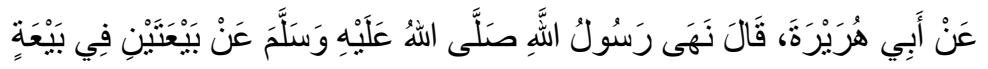

Artinya: dari Abi Hurairah, berkata: Rasulullah shallallahu 'alaihi wasallam melarang melakukan dua penjualan dalam satu kali transaksi (HR. Ahmad) ${ }^{1}$

Hadits ini melarang dua akad menjadi satu, tetapi Adiwarman membagi akad gabungan ini menjadi dua macam pembagian, yaitu:

1. Akad Ta'alluq (bergantung), adalah akad yang terjadi jika pada dua akad yang saling bertautan, maka yang berlaku hanya 1 akad meskipun terdiri dari dua akad.

2. Akad Shafqatain fi Al-Shafqah, adalah satu akad yang di fasilitasi dengan dia akad sekaligus, sehingga menimbulkan ketidakjelasan dalam akad mengenai akad yang akan diterapkan. Akad ini harus memenuhi tiga unsur utama yaitu, kesamaan objek, kesamaan pelaku dan kesamaan waktu. ${ }^{2}$

Akad Al-Ijarah Al-Muntahiyah Bittamlik merupakan akad gabungan antara akad ijarah dengan akad jual beli atau akad pemberian (hibah) di akhir masa sewa. Akad ini mempunyai 2 faktor kesamaan dari 3 kesamaan Akad Shafqatain fi Al-Shafqah yaitu kesamaan objek akad dan kesamaan pelaku. Kesamaan objek terjadi ketika diakhir akad penjual akan diberikan pilihan untuk memindahkan kepemilikan baik dengan cara jual beli dengan harga simbolis atau memberikan dengan cara hibah, tetapi dalam akad AlIjarah Al-Muntahiyah Bittamlik pemindahan kepemilikan hanya bisa dilakukan jika angsuran yang di wajibkan harus lunas atau tidak punya tanggungan sama sekali. Kesamaan pelaku pada akad Al-Ijarah Al-Muntahiyah Bittamlik yaitu sama, antara bank dan nasabah.

\footnotetext{
${ }^{1}$ Ahmad bin Muhammad bin Hanbal bin Hilal bin Asad Asy-Syaibani, Musnad Ahmad, (Muassasah AlRisalah, 2001) Hadits No. 10535.

2 Adiwarman A. Karim, Bank Islam..., h. 48-49.
} 
Ulama madzhab Hanafiyah melihat penggabungan dua akad menjadi satu berpendapat pihak yang melakukukan akad memiliki kebebasan dalam menentukan syarat dalam sebuah akad, dan itu menurut mereka adalah boleh (mubah) dengan syarat tidak bertentangan dengan syariat islam. Ulama malikiyah juga membolehkan penggabungan dua akad menjadi satu, selama tidak ada unsur menafikan salah satu atau keduanya. Begitu pula ulama madzhab syafi'i dan hambali membolehkan penggabungan antara dua akad dengan diakhiri dengan akad hibah. ${ }^{1}$

\section{PENUTUP}

Al-Ijarah Al-Muntahiyah Bittamlik adalah akad penggabungan antara dua akad yaitu akad sewa (Ijarah) dengan hak pemindahan kepemilikan di akhir akad setelah pemenuhan kewajiban tanggungan dari nasabah ke pihak bank. Meskipun ada klausa dalam hadits nabi yang melarang penggabungan akad dalam akad yang lain, namun sebagian besar ulama membolehkan akad ini selama tidak ada unsur penafian dalam salah satu akad. Majma' Fiqh Islami dalam sidangnya juga memperbolehkan akad ini dengan beberapa kriteria.

\footnotetext{
${ }^{1}$ Dimyauddin Djuwani, Pengantar Fiqh Muamalah, (Yogyakarta: Pustaka Pelajar, 2008), h. 131.
} 


\section{DAFTAR PUSTAKA}

Adiwarman A. Karim, Bank Islam Analisis Fiqih dan Keuangan, Cetakan ke-3, Jakarta: Raja Grafndo Persada, 2006.

Ahmad bin Muhammad bin Hanbal bin Hilal bin Asad Asy-Syaibani, Musnad Ahmad, Muassasah Al-Risalah, 2001.

Dimyauddin Djuwani, Pengantar Fiqh Muamalah, Yogyakarta: Pustaka Pelajar, 2008.

Fatwa Dewaan Syariah Nasional No. 27/DSNMUI/ III/2002 tentang Al-Ijarah AlMuntahiyya Bi Al-Tamlik.

Hasbi Ramli. Teori Dasar Akutansi Syariah. Jakarta: Renaisan, 2005.

Kompilasi Hukum Ekonomi Syariah (KHES)

Mahmud Abdul Karim Ahmad Irsyid, Asy-Syamil Fi Muamalat Wa Amaliyatil Masharif Al-Islamiyah, Jordania: Darun Nafais, 2007.

Muhammad Mushtafa az-Zuhaili, al-Qawaid al-Fiqhiyyah wa Tathbiqatuha fi alMadzahib al-Arba'ah.

Muhammad Syaf'i Antonio, Bank Syariah: dari Teori ke Praktik, Jakarta: Gema Insani, 2001.

Muhammad. Manajemen Pembiayaan Bank Syari'ah. Yogyakarta: UPP Akademi Manajemen Perusahaan YKPN 2005.

Undang-Undang Republik Indonesia tentang Perbankan Syariah Nomor 21 Tahun 2008, Yogyakarta: Pustaka Mahardika, 2011.

Wahbah Zuhaili, Al-Fiqhu Al-Islami Wa Adillatuhu, Damaskus: Darul Fikri. 